\title{
Algal-Bacterial Synergy for Lipid Production and Nutrient Removal in Tofu Liquid Waste
}

\author{
Shinta Elystia1*, Lely Rahmawati Saragih¹, Sri Rezeki Muria² \\ ${ }^{1}$ Department of Environmental Engineering, Faculty of Engineering, Riau University, Indonesia, 28293, \\ Panam, Pekanbaru, Indonesia \\ ${ }^{2}$ Department of Chemical Engineering, Faculty of Engineering, Riau University, Indonesia, 28293, Panam, \\ Pekanbaru, Indonesia
}

\begin{abstract}
Energy diversification using microalgae biomass offers a solution to the fossil fuel crisis, which has become a global issue. Chlorella sp. is a microalga that can produce lipids and reduce chemical oxygen demand (COD) in liquid waste. In this research, we used Chlorella sp. to produce lipids and reduce COD in tofu liquid waste. This research aimed to identify the interaction between a complex microorganism, as a decomposer agent, with the addition of the photosynthetic microalgae Chlorella sp. as an oxygen producer to reduce COD in tofu liquid waste. Moreover, we aimed to determine the interaction between Chlorella sp. and a bacterial consortium for microalgae growth and lipid production. This study was conducted in batches with the addition of bacteria at five different concentrations (\% v/v): 0 (no addition), up to $0.25,0.50,0.75$, and 1 . Cultivation was conducted for 13 days with solar irradiation in a photobioreactor. As a result, the highest density and the highest growth rate were obtained from the treatment with $1 \%$ bacteria, achieving as many as $5.65 \times 10^{6} \mathrm{cell} / \mathrm{mL}$ and 0.21 day. The $1 \%$ treatment was able to produce lipids and COD removal efficiencies of $20.93 \%$ and $96.30 \%$ at the best-removing detention times, which both occurred on the $13^{\text {th }}$ day of cultivation.
\end{abstract}

Keywords: Bacteria; Chlorella sp.; COD; Lipid; Tofu liquid waste

\section{Introduction}

The energy crisis and fossil fuels present environmental problems that have become a global issue. The availability of fossil fuels, which are increasingly depleting, accompanies ever-increasing consumption levels. Indonesia's reserves and production of petroleum (fossil) fuels have decreased by $10 \%$ each year, and the country's average oil consumption level has increased by $6 \%$ per year. In addition to this limited availability, the fossil-fuel burning process also produces greenhouse gas emissions, such as carbon dioxide $\left(\mathrm{CO}_{2}\right)$, which certainly harm the environment (Kuncahyo et al., 2013).

Energy diversification through the creation of renewable energy sources, such as biodiesel, offers a solution to the fossil fuel crisis. Microalgae are believed to be a good renewable energy source because of their rapid growth rate and ability to be cultivated in wastewater. Alga lipids could serve as an ideal feedstock for high-energy-density transportation fuels, such as biodiesel (Jegathese and Farid, 2014). Microalgae can 
produce high enough lipids ( $\pm 65 \%$ in dry weight) to be converted into biodiesel (Skill, 2007).

During the microalgae cultivation process, growth rates can be increased by adding bacteria to growth media. Bacteria, as a promoting agent, can increase microalgae biomass during cultivation. Increased biomass in algal cultivation increases lipid levels from these microalgae. In bacteria-algae symbiosis systems, bacteria can release $\mathrm{CO}_{2}$, which benefits algal growth. Meanwhile, microalgae can provide $\mathrm{O}_{2}$ via photosynthesis and produce nutrients for bacterial growth (Sayre, 2010). Ferro et al. (2019) reported that some bacteria can achieve high efficiency in removing pollutants from wastewater and promote algal biomass production through metabolic complementarity.

The microalgae cultivation system requires a medium with sufficient nutrients for growth. One growing medium that can be used to cultivate microalgae is tofu liquid waste (Jayanudin and Syaichurrozi, 2016). Elystia et al. (2020) reported that the cultivation of microalgae in tofu liquid waste under sterile conditions can produce algae cells of $8 \times 10^{5}$ cells/mL with a lipid content of $27.12 \%$, reducing the COD levels with $73.91 \%$ efficiency. Nugroho et al. (2016) reported that the cultivation of Chlorella Vulgaris with the addition of Azospirillum in tofu liquid waste can produce algae cells of $5.56 \times 10^{6}$ cells $/ \mathrm{mL}$, while cultivation without the addition of these bacteria can only produce algae cells of $3.07 \times 10^{6}$ cells/mL. Restuhadi et al. (2017) also reported that the use of a symbiosis of Chlorella sp. and a bacterial consortium reduced COD in palm oil mill effluent (POME) with an 82.7\% removal efficiency. These studies have shown that the addition of bacteria into microalgae growing media can support algal growth and reduce pollutants in wastewater media. The current research observed a reduction of pollutants and algal growth in tofu liquid waste, as well as the effects of adding a bacterial consortium containing Lactobacillus sp., Actinomycetes, and nitrifying bacteria on lipid levels produced by microalgae grown in tofu liquid waste. As growth-promoting agents and decomposers, bacteria help grow microalgae and reduce pollutants. In the processes of lipid production and pollutant reduction, microalgae and bacteria conduct symbiosis that allows bacteria to use the $\mathrm{O}_{2}$ produced by microalgae, in turn producing $\mathrm{CO}_{2}$ and growth-promoting substances as a byproduct of their respiratory metabolism that microalgae can use to grow (Siregar, 2012).

\section{Methods}

\subsection{Microalgae and Bacteria}

The Chlorella sp. microalgae used in this research came from the Alga Research Centre Laboratory at Riau University's Faculty of Fisheries and Marine Sciences. Meanwhile, the bacteria used were commercial bacteria that contained a consortium of Lactobacillus sp., Actinomycetes, and nitrifying bacteria.

\subsection{Cultivation Medium}

The medium used during this study's main cultivation process was tofu liquid waste, with the addition of a bacterial consortium that reduced pollutant levels and supplied nutrients to the microalgae.

\subsection{Seeding and Acclimatization}

Microalgae were cultivated by adding $100 \mathrm{~mL}$ of the microalgae Chlorella sp. and 400 $\mathrm{mL}$ of Dahril Solution medium into $3.5 \mathrm{~L}$ of distilled water. Cultivation was conducted for ten days with sunlight as its light source. Microalgae from cultivation then underwent an acclimation stage, which aimed to familiarize the microalgae with a growing medium in the form of tofu liquid waste. Physiologically, acclimated algal cells are more active and 
able to utilize more nutrients in liquid waste for their growth and metabolism (Irhamni and Munir, 2015).

Acclimatization was conducted for two weeks by gradually mixing the produced algae with tofu liquid waste. Acclimatization was then conducted in two stages: the first stage with a ratio of 50:50 microalgae versus tofu wastewater, and the second stage with a ratio of 75:25 microalgae versus tofu wastewater. During the seeding and acclimatization processes, the microalgae cells' abundance was calculated every 24 hours, using a hemocytometer, a microscope, and a hand counter to count the number of cells in each box area. Seeding and acclimatization were continued until a minimum cell density of $10^{6}$ cells $/ \mathrm{mL}$ was achieved. The microalgae cell count was calculated using the following formula (Schenk et al., 2008):

$$
N=\mathrm{n} \times 10^{4}
$$

where $N$ is the Chorella sp. cell count (cell/mL) and $n$ is the total number of cells calculated for each sample (cells).

\subsection{Cultivation Conditions}

During the study's main cultivation phase, the microalgae Chlorella sp. were grown in a medium of liquid tofu waste, in a photobioreactor with dimensions $30 \times 10 \times 20 \mathrm{~cm}$, with a working volume of $3 \mathrm{~L}$. The algae suspension was inserted using a photobioreactor at $25 \%$ of the working volume of $750 \mathrm{~mL}$. The tofu liquid waste, algal suspension, and bacterial consortium were added to the photobioreactor according to a variety of treatments: varying concentrations of the bacterial consortium in the photobioreactor by $0 \%, 0.25 \%$, $0.50 \%, 0.75 \%$, and $1 \% \mathrm{v} / \mathrm{v}$ (bacterial volume: work volume). The main cultivation was conducted for 13 days with sunlight as its light source. The tools' design during this cultivation process is shown in Figure 1.



Figure 1 Cultivation conditions

\subsection{Data Analysis and Processing}

We analyzed the following parameters: number of microalgae cells, temperature, $\mathrm{pH}$, MLSS (mixed liquor suspended solid), COD, and microalgae lipid levels. Our analysis was performed by taking Chlorella sp. from each photobioreactor for analysis of their lipid levels and cell growth, as well as the growing media to measure COD values. The number of algal cells was calculated using a hemocytometer, while $\mathrm{pH}$ was measured using a $\mathrm{pH}$ meter, based on SNI 06-6989.11-2004. MLSS was measured using the gravimetric method. Lipids were extracted using the Bligh Dyer method, and the COD value was measured using titrimetric analysis (SNI 6989.73-2009). Data on the number of microalgae cells, $\mathrm{pH}$, 
MLSS, temperature, lipid levels, and COD values were plotted graphically with logarithmic contact-time relations.

\section{Results and Discussion}

\subsection{Number of Microalgae Chlorella sp. Cells}

We calculated the number of Chlorella sp. microalgae cells using a hemocytometer and microscope every 24 hours during the cultivation process. The initial density of Chlorella sp. added to each photobioreactor was $1.66 \times 10^{6}$ cells $/ \mathrm{mL}$. The total cell microalgae Chlorella sp. in this study continued to improve until the end of cultivation; however, as Figure 2 shows, on the $12^{\text {th }}$ to $13^{\text {th }}$ days, the growth of the microalgae cells was less significant than it had been on the previous days. This finding shows that the microalgae Chlorella sp. were at the end of their exponential phase and beginning to enter their reduction log phase on the $13^{\text {th }}$ day. In a cultivation process with a detention time of more than 13 days, Chlorella sp. were presumed to enter their death phase, based on the decrease in algal growth at the end of the cultivation process, which indicated that the nutrients contained in the medium were decreasing. During the death phase, algal cells underwent lysis and no new cells grew. As Figure 2 shows, from the beginning to the end of cultivation, the treatment that added $1 \%$ decomposing bacteria into the culture medium resulted in the highest cell count, at $5.65 \times 10^{6}$ cells $/ \mathrm{mL}$. This result was due to the addition of bacteria at higher concentrations compared to the other treatments in this study. Microalgae and bacteria conduct symbiosis, through which bacteria can use the oxygen produced by microalgae and then produce $\mathrm{CO}_{2}$, which the microalgae can use (Siregar, 2012).



Figure 2 The relationship between bacteria-addition concentrations and numbers of Chlorella sp. microalgae cells

According to Dianursanti et al. (2016), $\mathrm{CO}_{2}$ acts as a carbon source for photosynthesis. The obtained carbon dioxide resulted from an excess of decomposing bacteria and dissolved $\mathrm{O}_{2}$ produced by algae using aerobic bacteria for the decomposition process (see in Figure 3).

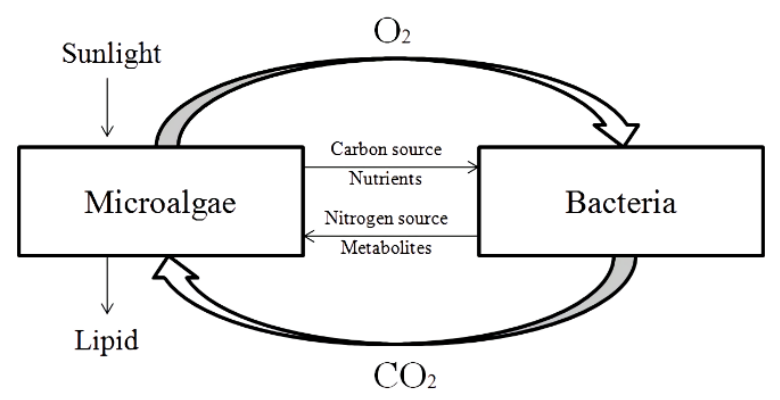

Figure 3 Algal-bacterial symbiotic schema 
Another important role for bacteria in algal growth is supplying vitamin B12, which is a micronutrient needed in algal growth. According to Kazamia et al. (2012), bacteria-as prokaryotic organisms-can synthesize vitamin B12 for microalgae. Decomposing bacteria through metabolism can also convert complex organic compounds into simple organic compounds, which microalgae can directly use as a nutrition source. Nitrifying bacteria are among the bacteria contained in a consortium, and they can form nitrate compounds through an overhaul of ammonia compounds. Nitrogen, as a nutrient, is absorbed by aquatic plants, generally in the form of nitrates. So, nitrate plays an important role in algal growth events in water (Kirchman, 2000). Microalgae cells' increased density aligns with the number of substrates needed for the metabolism process. The amount of substrate needed can be supplied by the nitrogen content in tofu liquid waste. Microalgae require nitrogen in the form of nitrates as organic material to photosynthesize and produce new cells. The following reaction shows the use of $\mathrm{CO}_{2}$ and nutrients for algal cell formation (Prapta et al., 2012):

$$
\mathrm{NH}_{3}+7.62 \mathrm{CO}_{2}+2.53 \mathrm{H}_{2} \mathrm{O} \stackrel{\text { Light }}{\longrightarrow} \mathrm{C}_{7.62} \mathrm{H}_{8.06} \mathrm{~N}+7.62 \mathrm{O}_{2}
$$

\subsection{The Specific Growth Rate of the Microalgae Chlorella sp.}

The different growth rates for each treatment in our study are shown in Figure 4. These differences resulted from cells' ability to absorb nutrients in the culture media. Specific growth rate values can serve as benchmarks to determine media's carrying capacity on cell growth. A high growth rate means that a population increases faster because the rate of unity cells increases faster, so the harvest period is also faster. The cultivation medium is influenced by the nutritional factors of a given culture (Afriza et al., 2015). The bacterial consortium's role in the current research was to supply $\mathrm{CO}_{2}$ and organic materials in a simple form as a nutrient for the microalgae Chlorella sp. Nitrates, formed through nitrification by nitrifying bacteria contained in a consortium, can be directly used by microalgae as a nutrition source. Kirchman (2000) reported that nitrogen, as a nutrient, is absorbed by aquatic plants, generally in the form of nitrates, so nitrates play an important role in algal growth events.

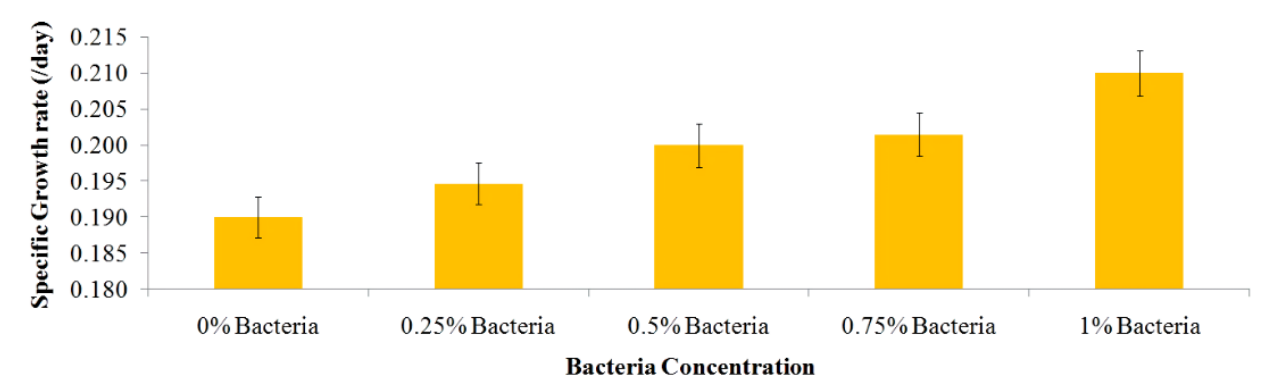

Figure 4 Chlorella sp. microalgae growth rate and variations in bacteria-concentration additions

\section{3. $p H$ Medium Cultivation of the Microalgae Chlorella sp.}

The $\mathrm{pH}$ medium cultivation parameter indicates the acidity of a medium, and it can affect the decomposition of organic compounds by bacteria (Pujiastuti and Suwartha, 2017). The medium's pH value during cultivation ranged from 6.51 to 8.78 in our study. The increase in $\mathrm{pH}$ resulted from the evaporation of ammonia and the activity of the microorganisms in a consortium of bacteria, which act as decomposers (Restuhadi et al., 2017). Ammonia $\left(\mathrm{NH}_{3}\right)$, which dissolves in water, releases ammonium ions $\left(\mathrm{NH}_{4}^{+}\right)$. Ammonium was produced by the dissociation process of ammonium hydroxide dissolved in water. The increase in $\mathrm{pH}$ was also caused by photosynthesis activity by the microalgae 
Chlorella sp. Carbon dioxide is a major component in the photosynthesis process. The decrease in $\mathrm{CO}_{2}$ levels in water causes $\mathrm{pH}$ levels to increase from an acidic state to a neutral or alkaline state. Microorganisms decompose organic matter in wastewater using oxygen and photosynthetic activity, which takes dissolved $\mathrm{CO}_{2}$ in the form of $\mathrm{H}_{2} \mathrm{CO}_{3}-$, increases $\mathrm{pH}$ levels. The increase in $\mathrm{pH}$ that we noted until the end of cultivation aligned with the increasing number of Chlorella sp. Restuhadi et al. (2017) also suggested that an increase in $\mathrm{pH}$ aligned with microalgae's increasing density and nutrient utilization rate.

\subsection{The Medium Cultivation Temperature for the Microalgae Chlorella sp.}

The medium temperature during the microalgae cultivation process is an important factor to consider. At temperatures below $16^{\circ} \mathrm{C}$, microalgae can still grow slowly. However, at very high temperatures, some microalgae can die or undergo lysis (break). A temperature range of $25-35^{\circ} \mathrm{C}$ is optimal for the growth of Chlorella sp., increasing the organisms' biological activity by two to four times. The temperature during the current study yielded results that had met the criteria for Chlorella sp. medium growth until the end of the cultivation process, and no temperature fluctuations were too high. The study's temperature fluctuations were influenced by the weather during the cultivation process. As Figure 5 shows, the temperature of the tofu liquid waste medium during cultivation ranged from 29 to $35^{\circ} \mathrm{C}$. This temperature range was within the growth limits for Chlorella sp., which can live and grow optimally in a temperature range of $5-35^{\circ} \mathrm{C}$.

\subsection{MLSS (Mixed Liquor Suspended Solid) Values during Cultivation}

MLSS concentrations in this study ranged from 2,000 to 3,6000 mg/L (see Figure 5). The increases in MLSS values were influenced by the amount of oxidized organic matter. Organic matter is oxidized by microorganisms in order to grow. Furthermore, the more organic matter is oxidized, the more MLSS concentrations in a reactor increase. In our reactors with high bacterial and microalgae concentrations, MLSS values were high. According to Septiani (2014), the MLSS values depend on the concentrations of algae, bacteria, and non-volatile components. Therefore, MLSS values depended on the concentrations of algae and bacteria in our reactors. The control reactor showed a lower MLSS value than the other reactors. In this study, MLSS values represent the concentration of algal biomass and bacteria in the studied waste. Meanwhile, the number of microalgae was represented directly by the number of microalgae cells.

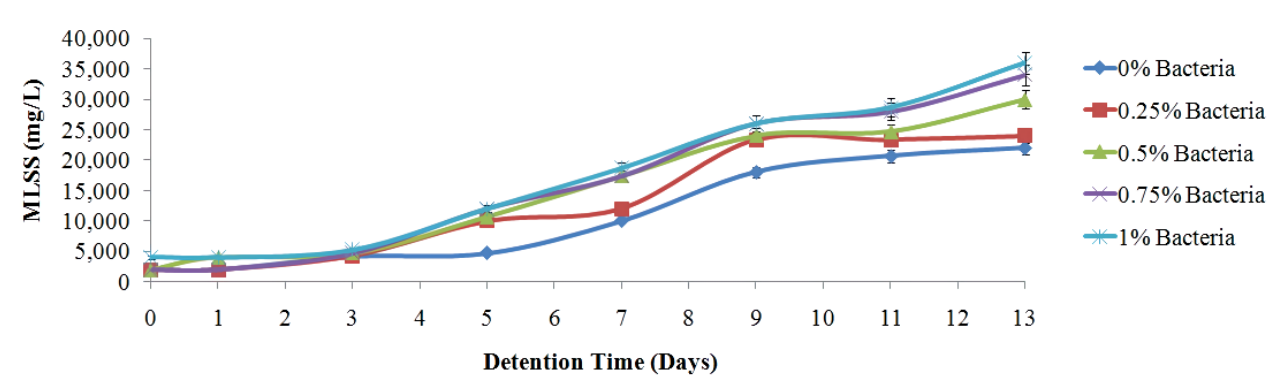

Figure 5 MLSS values during cultivation

\subsection{COD Removal Efficiency}

This research used tofu liquid waste as a growth medium for the microalgae Chlorella sp. Apart from being a source of nutrition for the microalgae's growth, the liquid tofu waste medium also decreased the COD levels in the liquid waste itself. As Figure 6 shows, each time a bacterial consortium yielded significantly different COD removals at the end of the processing process, the COD removal efficiency was higher, and the variation in the 
bacterial-consortium addition increased. On the seventh day of cultivation, significant changes in COD values were observed and attributed to bacterial contributions. Also, on the seventh and $13^{\text {th }}$ days, significant decreases in COD value were confirmed by agreement without using bacteria (control). The level of the decreases in COD values at the time of administration with this bacterium resulted from the influence of the bacterial consortium, which acted as a decomposer. Meanwhile, the slower decline in COD values in the control photobioreactors was due to the removal of organic material carried out by the microalgae Chlorella sp.

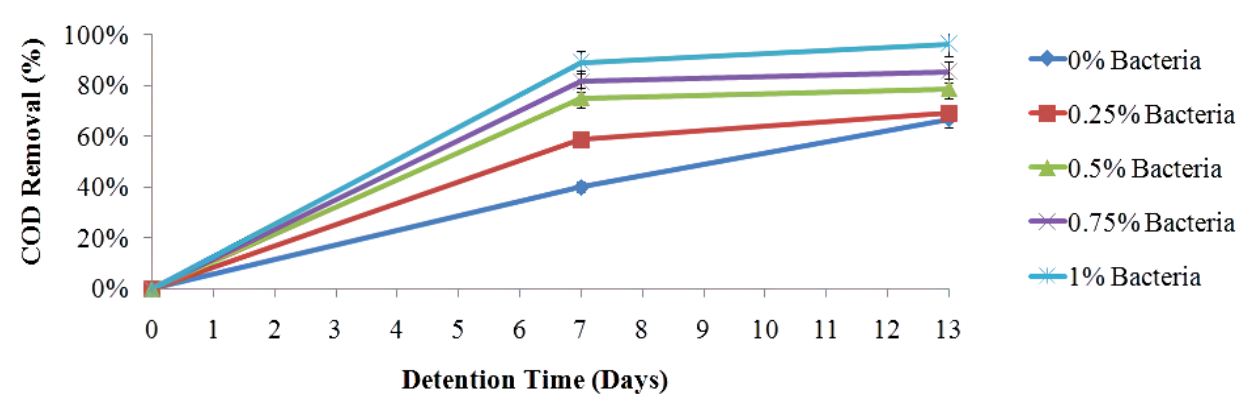

Figure 6 COD removal efficiency

The decreasing COD values with the addition of commercial bacteria, such as EM4, BDECO3, and Starbact, tends to occur faster than without the addition of bacteria (control) (Restuhadi et al., 2017; Munawaroh et al., 2013;). This tendency shows the activity of lactic acid bacteria (Lactobacillus sp.) contained in the consortium, which accelerates the overhaul of organic matter. A decrease in COD values indicates the decomposition of organic material into simpler substances (Sarono et al., 2016). In the current research, the highest COD removal efficiency was found in the photobioreactors with a bacterial-consortium concentration of $1 \% \mathrm{v} / \mathrm{v}$. In this trial, the liquid waste was obtained with a final COD concentration of $160 \mathrm{mg} / \mathrm{L}$ and removal efficiency of $96.30 \%$. Due to the high number of bacteria contained in the photobioreactors that could produce $\mathrm{CO}_{2}$ for microalgae growth, when the algae cells and bacteria contained in photobioreactors were under optimal conditions, their removal was also optimal. This bacterial consortium contained decomposing bacteria in the form of Lactobacillus sp., Actinomycetes sp., and nitrifying bacteria, which play an active role in degrading complex organic compounds into simple compounds that can be used by microalgae as a nutrient source. According to Munawaroh et al. (2013), Lactobacillus sp. acts as a hydraulic bacterium in the treatment of liquid waste and can break down complex organic molecules into simple molecules. Actinomycetes sp. plays a role in decreasing pollutant parameters and increasing nutrients, as well as nitrification bacteria, which can decompose carbohydrates, proteins, and fats in organic liquid waste and eliminate odors from liquid waste. The ability to decrease COD values was due to interactions between the decomposing bacteria found in the consortium and the microalgae Chlorella sp. Microalgae use $\mathrm{CO}_{2}$ as their main carbon source for the synthesis of new cells, and they release $\mathrm{O}_{2}$ through the mechanism of photosynthesis. The carbon dioxide obtained resulted from an overhaul of the organic matter found in tofu liquid waste by aerobic bacteria through the decomposition process.

Aeration is another factor that accelerates the reduction of tofu liquid waste pollutants, providing the same function as stirring. Due to the use of aeration, an $\mathrm{O}_{2}$ supply and sunlight can affect more liquid waste and contact between algae and nutrients in the waste. Oxygen is needed to help the decomposition process of organic matter in liquid 
waste by decomposing bacteria, while sunlight is needed to assist the photosynthesis of the microalgae Chlorella sp. (Restuhadi et al., 2017).

\subsection{Chlorella sp. Lipid Levels}

The lipid content of the microalgae during cultivation was directly proportional to the amount of microalgae biomass produced. The lipids produced by microalgae decrease when little biomass is produced. The increase in microalgae lipids was influenced by several factors, such as nutrition and harvesting time. According to Richmond (2013), nitrogen in the form of nitrate has an important function in the process of cell metabolism, including photosynthesis. High chlorophyll content causes efficient photosynthesis. Nitrogen is a macronutrient that can affect the growth of microalgae in the activities of cell metabolism, such as transportation, catabolism, and assimilation. The role of a bacterial consortium in supplying macronutrients as nitrates to microalgae constitutes one form of symbiosis that benefits microalgae's cell formation and lipid productivity.

At detention times on Day 0 and Day 3 of our cultivation, microalgae were in the adaptation phase. In its initial adaptation phase, the lipid content of the Chlorella sp. was quite low (see Figure 7). This finding presumably resulted from the early adaptation phase, during which microalgae synthesize more proteins for growth and the multiplication of cell numbers. During this phase, microalgae undergo more protein synthesis, which is used for DNA synthesis. DNA synthesis is then used as a material in the process of cell division. The results of photosynthesis are stored as a form of cell adaptation to sustain life in extreme environments (Ehrenfeld and Cousin, 2000). The addition of a bacterial consortium of $1 \% \mathrm{v} / \mathrm{v}$ resulted in our study's highest lipid content, at $20.93 \%$, at the end of the cultivation's exponential phase on Day 13.

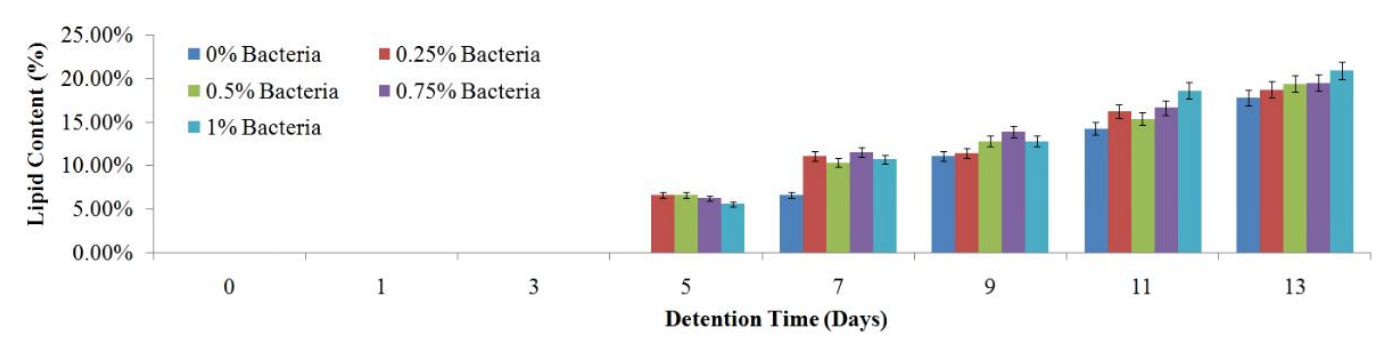

Figure 7 Lipid content of microalgae Chlorella sp.

The highest lipid content occurred in the highest bacterial consortium concentration. This result was due to the increasing number of bacteria contained in this study's photobioreactors causing more $\mathrm{CO}_{2}$ to be used by the microalgae for growth. The higher the biomass of microalgae, the more lipids are produced. The process of microalgae's cellular photosynthesis can convert $\mathrm{CO}_{2}$ into glucose and lipid. The concentration of $\mathrm{CO}_{2}$ contained in photobioreactors had a relatively positive effect on increasing lipid levels (Dianursanti et al., 2016). As Figure 8 shows, during their lag phase, microalgae do not produce lipids.

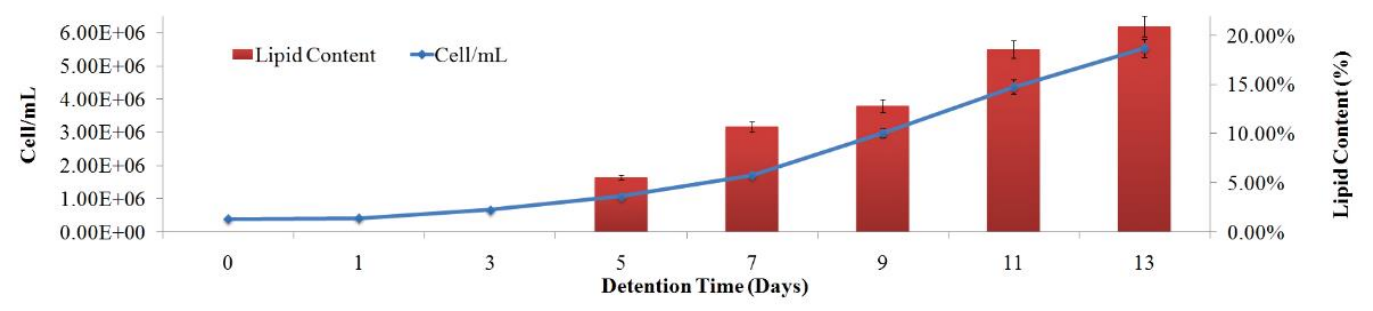


Figure 8 Relationship between microalgae growth and lipid content at optimal variables

The lipid content produced by microalgae at the end of their exponential phase exceeds the amount produced during the exponential phase itself. Widianingsih et al. (2011) suggested that, when nutrients in a culture medium have started to outrun microalgae, more photosynthesis would result in more lipids. Bellou and Aggelis (2013) also suggested that, when nitrogen is still available in a medium, microalgae synthesize proteins for cell division. But when the nitrogen in a culture medium begins to decrease, more microalgae photosynthesize, resulting in lipids.

\section{Conclusions}

This study has demonstrated that bacteria and algae interact with each other to significantly reduce COD in tofu liquid waste, which can promote algal growth. Meanwhile, COD removal and algal growth with a lower bacteria addition (control) performed no better than treatments adding bacteria. The higher microalgae's higher biomass, the more lipids are produced. The produced lipids could serve as a biodiesel feedstock to overcome the fossil fuel crisis. The optimal conditions for COD-value reduction, growth, and lipid levels of the microalgae Chlorella sp. were attained with a treatment that added a $1 \%$ bacterial consortium. The study's COD-value removal efficiency and lipid content of microalgae under optimal conditions stood at $96.30 \%$ and $20.93 \%$, respectively.

\section{Acknowledgements}

The authors would like to express their gratitude to the Alga Research Centre Laboratory at the Faculty of Fisheries and Marine Sciences and the Laboratory of Control and Prevention of Environmental Pollution at the Faculty of Engineering-both at the University of Riau - for their support in this research.

\section{References}

Afriza, Z., Diansyah, G., Purwiyanto, A.I.S., 2015. Effect of Giving Urea $\left(\mathrm{CH}_{4} \mathrm{~N}_{2} \mathrm{O}\right)$ with Different Doses on Cell Density and Growth Rate of Porphyridium sp. on Laboratory Scale Phytoplankton Culture. Maspari Journal, Volume 7(2), pp. 33-40

Bellou, S., Aggelis, G., 2013. Biochemical Activities in Chlorella sp. and Nannochloropsis Salina During Lipid and Sugar Synthesis in a Lab-Scale Open Pond Simulating Reactor. Journal of Biotechnology, Volume 1 (1), pp. 1-12

Dianursanti, S.A., Delaamira, M., 2016. Utilization of Chlorella Vulgaris to Fixate a High Concentration of Carbon Dioxide in a Compost-Based Medium. International Journal of Technology, Volume 7 (1), pp. 168-175

Ehrenfield, J., Causin, J.L., 2000. Ionic Regulation of the Unicellular Green Alga Dunaliella Tertiolecta. The Journal of Membrane Biology, Volume 7(1), pp. 47-58

Elsytia, S., Larasati, D., Muria, S.R., 2020. Produksi Lipid dari Mikroalga Scenedesmus sp. pada Media Limbah Cair Tahu dengan Variasi Konsentrasi Limbah dan Photoperiod. AL-ARD: Jurnal Teknik Lingkungan, Volume 5(2), pp. 54-61

Elsytia, S., Dian, L., Sri, R., S., 2020. Lipid Production from Microalgae Scenedesmus sp. in Tofu Liquid Waste Medium with Variation in Tofu Liquid Waste Concentration and Photoperiod. AL-ARD: Journal of Environmental Engineering, Volume 5(2), pp. 54-61

Ferro, L., Colombo, M., Posadas, E., Funk, C., Munoz, R., 2019. Elucidating the Symbiotic Interactions between a Locally Isolated Microalga Chlorella Vulgaris and Its Co- 
Occurring Bacterium Rhizobium sp. in Synthetic Municipal Wastewater. Journal of Applied Phycology, Volume 3(1), pp. 2299-2310

Irhamni, Munir, E., 2015. Kultivasi Mikroalga untuk Bioteknologi Biomassa sebagai Energi Terbarukan (Cultivation of Microalgae for Biomass Biotechnology as Renewable Energy). Jurnal Teknik Lingkungan, Volume 3(1), pp. 80-89

Jayanudin, J., Syaichurrozi, I., 2016. Kultivasi Spirulina Platensis pada Media Bernutrisi limbah Cair Tahu dan Sintetik (Potential of Tofu Liquid Waste as a Spirulina Plantesis Growing Media). Jurnal Bahan Alam Terbarukan, Volume 5(2), pp. 68-73

Jegathese, S.J.P., Farid, M., 2014. Microalgae as a Renewable Sources of Energy: A Niche Opportunity. Journal of Renewable Energy, Volume 2014 (1), pp. 1-10

Kazamia, E., Czesnick, H., Nguyen, V., Sherwood, E., Sasso, S.D., Smith, G., 2012. Mutualistic Interaction between Vitamin B12 Dependent Algae and Heterotrophic Bacteria Exhibit Regulation. Environmental Microbiology, Volume 1(1), pp. 1-11

Kirchman, D.L., 2000. Microbial Ecology of the Oceans. Willey-Lis, New York

Kuncahyo, P., Zuhdi, A., Fathallah, S., 2013. Prediction Analysis of the Potential of Biodiesel Raw Materials as Supplement for Diesel Motor Fuel in Indonesia. Engineering Journal, Volume 2(1), pp. 62-66

Munawaroh, U., Sutisna, M., dan Pharmawati, K., 2013. Penyisihan Parameter Pencemar Lingkungan pada Limbah Cair Industri Tahu menggunakan Efektif Mikroorganisme 4 (EM4) serta Pemanfaataanya (Removal of Environmental Pollution Parameters in Tofu Liquid Waste Using Effective Microorganism 4 (EM4) and Their Utilization). Jurnal Reka Lingkungan. Volume. 1 (2), pp. 1-12

Nugroho, W., Luthfi, M., Susilo, B., 2016. Promoting Growth of Chlorella Vulgaris in Secondary Wastewater Treatment Effluent of Tofu Industry Using Azospirilium sp. International Journal on Advance Science Engineering Information Technology, Volume 6(3), pp. 289-294

Prapta, S., Slamet, A., Hermana, J., 2012. Studi kemampuan Alga zdalam menyerap karbon (carbonsink) sebagai upaya alternatif dalam mengurangi emisi karbon $\left(\mathrm{CO}_{2}\right)$ (Alga Capability in Absorbing Carbon as an Alternative in Reducing Carbon ( $\left.\mathrm{CO}_{2}\right)$ Emissions). Scientific of Environmental Tech IX, pp. 1-7

Pujiastuti, D.R., Suwartha, N., 2017. Enhancing Removal Efficiency of Ammonia and Nitrate in Shrimp Farm Wastewater using Biofloc Technology and Effective Microorganism S4 (EM4). International Journal of Technology, Volume 8(6), pp. 1021-1030

Restuhadi, F., Zalfiatri, Y., Pringgondani, DA. 2017. Pemanfaatan Simbiosis Mikroalga Chlorella sp. dan Starbact Untuk Menurunkan Kadar Polutan Limbah Cair Sagu (Utilization of Symbiosis Microalgae Chlorella sp. and Starbact to Reduce Levels of Sago Liquid Waste Pollutants.) Jurnal Ilmu Lingkungan. 11(2), pp. 140-153

Richmond, A., 2013. Handbook of Microalgal Culture: Biotehchnology and Applied Phycology. Blackwell Science Ltd., United Kingdom

Sarono, S., Suparno, O., Supriatin, S., Hasanudin, U., 2016. The Performance of Biogas Production from POME at Different Temperatures. International Journal of Technology, Volume 7(8), pp. 1413-1421

Sayre, R., 2010. Microalgae: The Potential for Carbon Capture. Bioscience, Volume 60(9), pp. 722-727

Schenk, P., Thomacytometers-Hall, S., Stephens, E., Mark, U., Mussgnug, J., Posten, C., Kruse, O., Hankamer, B., 2008. Second Generation Biofuels: High Efficiency Microalgae for Biodiesel Production. Journal of Bioenergy Resource, Volume 1(1), pp. 20-43

Septiani, W., D., Slamet, A., Hermana., J, 2014. Pengaruh Konsentrasi Substrat terhadap Laju Pertumbuhan Alga dan Bakteri Heterotropik pada Sistem HRAR (Effect of 
Substrate Concentration on Growth Rates of Algae and Heterotropic Bacteria in HRAR Systems). Jurnal Teknik. Volume 3(2), pp. 98-103

Siregar, B., I.T., Hermana., J., 2012. Identifikasi Dominasi Genus Alga pada Air Boezem Morokembrangan sebagai Sistem High Rate Algae Pond (HRAP) (Identification of The Domination of Algae's Genus In MorokembranganBoezem Water As A High Rate Algae Pond (HRAP) System). Jurnal Teknik Lingkungan, Volume. 3 (2), pp. 1-33

Skill, S., 2007. Microalgae Biofuels. Marine Futures Conference. Journal of National Marine Aquarium, p. 18

Widianingsih, W., Hartati, R., Endrawati, H., Yudiati, E., and Iriani, V.R., 2011. Pengaruh Pengurangan Konsentrasi Nutrien Fosfat dan Nitrat Terhadap Kandungan Lipid Total Nannochloropsis oculate (Effect of Reduction of Phosphate Nutrient Concentration and Nitrate on Total Lipid Content of Nannochloropsis Oculata). Jurnal Ilmu Kelautan. Vol. 16 (1), pp. 24-29 